\title{
TECHNOLOGICAL MOISTURE AS A CAUSE OF MOULDS ON BUILDING PARTITIONS
}

\author{
Marlena PIONTEK, Katarzyna LUSZCZYŃSKA ${ }^{1}$, Hanna LECHÓW \\ University of Zielona Góra, Zielona Góra, Poland
}

\begin{abstract}
The intense pace of construction work means that technical materials contain so-called technological moisture, which enables the development of biodeteriogenic organisms on building partitions. This article presents the mycological analysis of two buildings in Zielona Góra, whose building partitions were affected by colour deposits. In the first building (a block of flats in the shell and core condition) 7 species of moulds were determined, of which the dominant one was Cladosporium herbarum. In the second building (public utilities building) changes on the walls appeared just after refurbishment and were caused by a species of mould called Strachybotrys chartarum which is hazardous to human and animal life.
\end{abstract}

Keywords: technological moisture, biodeterioration, moulds, mould in the building

\section{INTRODUCTION}

Papers published by many authors indicate that moisture in buildings constitutes a serious issue, not only in the apartments in Poland, but also all over Europe. Moisture inside a building is the main reason for damage to building partitions [14]. The main symptoms of the negative effects of moisture on buildings include: intensified biodeterioration of building partitions (mechanical, biological and

\footnotetext{
${ }^{1}$ Corresponding author: University of Zielona Góra, Faculty of Civil Engineering, Architecture and Environmental Engineering, Institute of Environmental Engineering, Department of Applied Ecology, Z. Szafrana st 15, 65-516 Zielona Góra, Poland, e-mail: k.luszczynska@iis.uz.zgora.pl, tel. 683282681
} 
chemical), deterioration of physical and mechanical properties of materials or deterioration of hygienic-sanitary conditions of rooms [15].

Construction, finishing and insulation materials are easily colonized by moulds because of their porous structure and occasional moisture [16]. Porous materials in building partitions practically always contain water in natural conditions. If the permissible level of moisture is exceeded, then negative phenomena may occur within a building. In the building practice, the term "moisture" refers to water contained in the material, soil or air, which does not exert hydrostatic pressure on the building elements. If, however, the water exerts pressure, the term "water under pressure" or just "water" is used. The moisture in a building may appear, among other ways, as a result of the capillary rise of groundwater, internal and surface condensation of water vapour contained in the air, water sorption from the air, the effect of process water or atmospheric precipitations. The moisture quantity in the air inside buildings may be determined by means of: the moisture content, the relative humidity, the partial pressure of water vapour, the dew point temperature and the wet bulb temperature [15].

The dew point temperature is very useful for the evaluation of the sources of wall dampness. It allows for the determination of whether the dampness is the result of condensation of water contained in the air or whether it comes from outside the building. The dew point temperature is not constant and depends on the air humidity and temperature. The higher the content of moisture in the air is, the higher the dew point temperature is. Moisture condenses on a technical material when its temperature is lower than the dew point temperature. If the internal relative humidity does not exceed $40-45 \% \mathrm{RH}$, it is the fault of excessively cold partitions that the moisture condenses on the surface of the technical material. In a moderate climate, the risk becomes greater in Spring and Autumn, when nights are cool and days are warm.

The most important factors for and mycotoxin production amd growth are temperature, water activity $\left(\mathrm{a}_{\mathrm{w}}\right)$ and oxygen. The opimal temperature is $25-30^{\circ}$ $\mathrm{C}$ for most Penicilla and $30-40^{\circ} \mathrm{C}$ for most Aspergilli. If the temperature in the material is not uniform, the water activity can rise locally due to migration moisture to the cold areas, thus leading to fungal growth. The term water activity or equilibrium - relative humidity (ERH) is a measure of the unbound water in a material that is available for chemical and biological reactions. Water activity is defined as the ratio of water vapor pressure of a substance (p) to the vapor pressure of pure water $\left(p_{o}\right)$ at the same temperature (i. e., $\left.a_{w}=p / p_{o}\right)$. Therefore, ERH can be defined as water activity expressed as a percentage $\left(E R H=a_{w} \times 100\right)$. Water activity is not the same as moisture content, although materials that have high moisture levels are most likely to have greater water activity as compared to dry ones [4]. The moisture requirement for mould growth was studies by Grant et 
al. He found that the lowest water activity level recorded for growth on malt extra agar was 0.76 while for building materials such as painted woodchip wallpaper it was 0.79 . He also observed that increasing the temperature and the amount of nutrients led to a reduction in the water activity in building materials and levels should be kept below 0.80 [3]. Considering the minimum rate of hygroscopic balance, $\left(a_{w}-\right.$ min.) expresses the demand of mould moisture needed for germination and growth can be divided into three groups:

- primary colonizers, able to grow on and in less than 0.8 (and $<0.8$ ). These include species of: Wallemia, Penicillium, Aspergillus, and telemorfic form Eurotium,

- secondary colonizers, for which the $\mathrm{a}_{\mathrm{w}} \mathrm{min}$ is in the range 0.8-0.9 (mould fungi of the species: Cladosporium, Phoma, and Alternaria Ulocladium),

- tertiary colonizers (hydrophile), require at least 0.9 , (and $>0.9$ ). These are species such as: Stachybotrys, Trichoderma, Chaetomium and Aureobasidium $[5,8]$. Oxygen is usually necessary for the growth of fungi, but certain species can also grow under anaerobic conditions with the formation of ethanol and organic acids [13].

In European Community documentation, the Building Research Institute remarks that buildings should be designed and built in a manner which does not create any threat to the hygiene, health and environment of the dwellers and users as a consequence of moisture. It also emphasizes that moisture may affect the health of the building dwellers or users directly as a result of excessively low or high relative air humidity, and indirectly, contributing to the occurrence of moulds on surfaces and inside products and intensifying the development of dust mites [7]. In new buildings, which have not been even put into service yet, the issue of moulds on building partitions may also appear. Construction companies perform their work very fast and put the buildings into use equally fast. The pace of construction work causes significant technological defects in the new buildings. [10]. The materials used for the construction purposes contain the so called technological moisture, which is confined in the building, e.g. brick elements dry up after as many as 3 years and suporex dries up after even 5 years.

\section{METHODS AND MATERIALS}

\subsection{Sampling location}

Samples for microbiological analyses were collected from the building partitions of two buildings infested with moulds: a block of flats in the shell and core condition, which had not yet been put into use (Fig.1.) and from the walls of the public utilities building in Zielona Góra, where, as a consequence of excessively fast repair work, mould appeared on the renovated wall (Fig. 2.). The partition 
was renovated at the end of July and the beginning of August 2017, and the changes appeared in September of the same year.

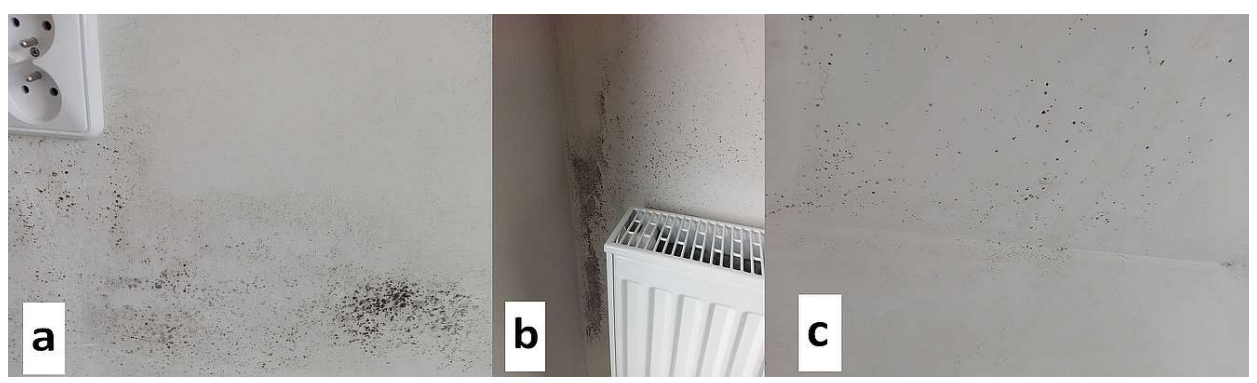

Fig. 1. View of the moulds on building partitions in one of the apartments in a block of flats before it was put to use: a- on the inner wall at the floor (apartment on the third floor), $\mathrm{b}$ - close to the corner on the inner wall, about $1.20 \mathrm{~m}$ above the floor, $\mathrm{c}$ - on the ceiling of the same room

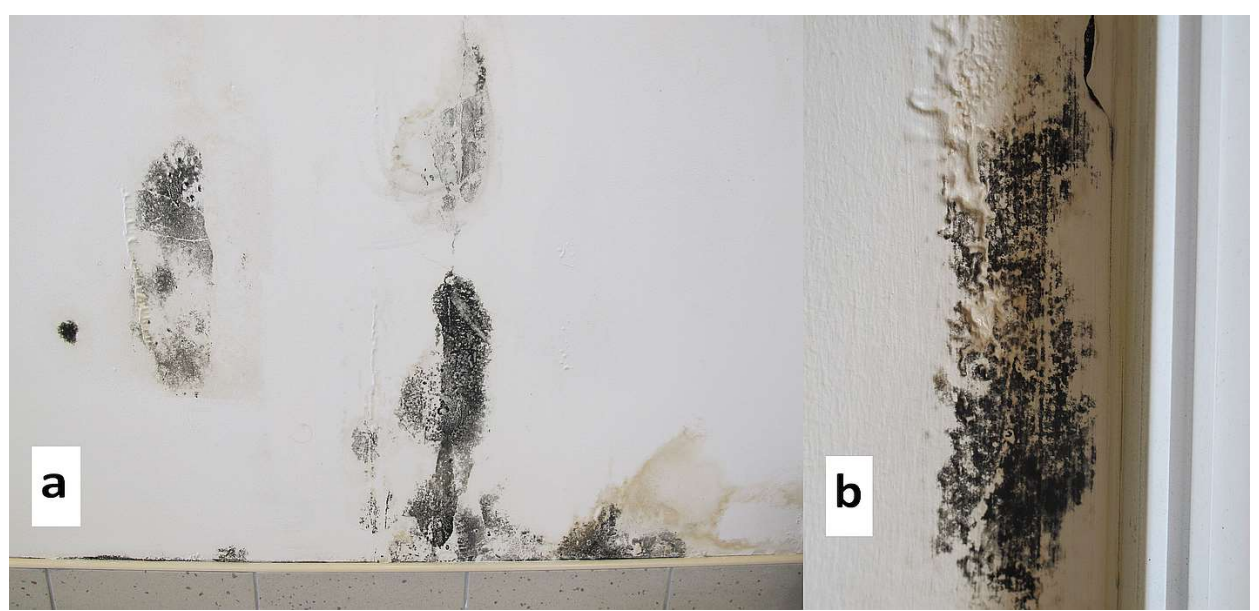

Fig. 2. Moulds on the wall of the corridor in the public utilities building in Zielona Góra: $\mathrm{a}$ - infestation on the outer wall of the lowest building storey, $\mathrm{b}$ - mould on the wall by the window on the same storey

\subsection{Testing methodology}

The mycological analysis was performed using the direct plating method. Samples of moulds were collected directly at the site of occurrence and transferred onto Petri dishes which contained the following media: MEA and Czapek - Dox Agar. The mycological analysis was performed in accordance with the methodology given by CBS (Centraalbureau voor Schimmelcultures), [13]. According to the direct plating method, small fragments of the material infested with moulds are transferred or spread onto Petri dishes containing the culture 
media [6]. The samples were then covered with white linen and incubated in a cultivation room at a room temperature between $18^{\circ}$ and $22^{\circ} \mathrm{C}$, maintaining the circadian rhythm of day and night. Pure (axenic) cultures were isolated from mixed starter cultures by their passaging on the media: Czapek-Dox and MEA. The time of plating, cultivation and observation for an isolated single species was 21 days $[8,9,11,12]$. The isolated strains were subjected to identification tests. A Nikon Eclipse 200 microscope and an Olympus SZX7 stereoscopic microscope were used for the observation of the moulds in the laboratory of the Institute of Environmental Engineering at the University of Zielona Góra.

Measurements of the relative humidity of wood, construction materials, air and the ambient temperature were performed with a Hygropen humidity meter. The humidity measurement consisted of the measurement of electrical resistance by the insertion of measuring needles into the structure of the partition.

\section{RESULTS}

Analysis of the biological material allowed for the identification of the moulds. The affinity of moulds to a given species was determined macroscopically and microscopically based on the morphological and physiological features by means of keys.

Table 1. Biodeteriogenic organisms on building partitions(developer's building, Zielona Góra)

\begin{tabular}{|c|l|c|c|}
\hline No. & \multicolumn{1}{|c|}{ Species } & $\begin{array}{c}\text { Frequency of } \\
\text { occurrence }\end{array}$ & $\begin{array}{c}\text { Minimal water actvities } \\
\left(\mathbf{a}_{\mathbf{w}}\right)[\mathbf{1}],[\mathbf{1 3}] \text { for growth }\end{array}$ \\
\hline 1. & Acremonium strictum W. Gams & numerous & 0.97 \\
\hline 2. & $\begin{array}{l}\text { Alternaria alternata (Fries) } \\
\text { Keissler }\end{array}$ & numerous & $0.85-0.88$ \\
\hline 3. & $\begin{array}{l}\text { Aureobasidium pullulans } \\
\text { (De Bary) Arnaud }\end{array}$ & numerous & $0.89-0.90$ \\
\hline 4. & $\begin{array}{l}\text { Aspergillus versicolor Vuillemin } \\
\text { Tiraboschi }\end{array}$ & single & 0.78 \\
\hline 5. & $\begin{array}{l}\text { Cladosporium herbarum } \\
\text { (Persoon) Link ex S.F.Gray* }\end{array}$ & very numerous & $\mathbf{0 . 8 5 - 0 . 8 8}$ \\
\hline 6. & Mucor racemosus Fresenius & numerous & 0.94 \\
\hline 7. & Penicillium chrysogenum Thom & single & $0.78-081$ \\
\hline 8. & Actinomycetes & single & - \\
\hline
\end{tabular}

* the dominant mould species in the analysed samples 
Table 2. Biodeteriogenic organisms on building partitions (corridor - the public utilities building in Zielona Góra)

\begin{tabular}{|c|ll|c|c|}
\hline \multicolumn{5}{|c|}{$\begin{array}{c}\text { Biodeteriogenic organisms on building partitions } \\
\text { (corridor) }\end{array}$} \\
\hline No. & \multicolumn{2}{|c|}{ Species } & $\begin{array}{c}\text { Frequency of } \\
\text { occurrence }\end{array}$ & $\begin{array}{c}\text { Minimal water } \\
\text { actvities (aw) } \\
\text { for growth [13] }\end{array}$ \\
\hline 1. & $\begin{array}{l}\text { Stachybotrys chartarum } \\
\text { Hughes* }\end{array}$ & (Ehrenb.) & very numerous & 0.94 \\
\hline 2. & Actinomycetes & numerous & - \\
\hline
\end{tabular}

* the dominant mould species in the analysed samples

The results of humidity measurements are presented in Table 3.

Table 3. Measurements of temperature and humidity on the wall infested with mould the public utilities building in Zielona Góra

\begin{tabular}{|c|c|c|c|c|c|c|}
\hline $\begin{array}{l}\text { Measurement } \\
\text { date }\end{array}$ & $\begin{array}{c}\text { Dew point } \\
\text { temp. } \\
{\left[{ }^{\circ} \mathrm{C}\right]}\end{array}$ & $\begin{array}{c}\text { Air } \\
\text { temp. } \\
{\left[{ }^{\circ} \mathrm{C}\right]}\end{array}$ & $\begin{array}{c}\text { Air } \\
\text { humidity } \\
{[\%]}\end{array}$ & $\begin{array}{c}\text { Dry } \\
\text { surface } \\
\text { humidity } \\
\text { without } \\
\text { infestation } \\
\text { [\%] RH }\end{array}$ & $\begin{array}{c}\text { Wet } \\
\text { surface } \\
\text { humidity } \\
\text { (with a } \\
\text { visible } \\
\text { damp } \\
\text { patch) } \\
\text { without } \\
\text { infestation } \\
\text { [\%] RH }\end{array}$ & $\begin{array}{c}\text { Humidity } \\
\text { of Surface } \\
\text { with the } \\
\text { biological } \\
\text { deposit } \\
\text { [\%] RH }\end{array}$ \\
\hline \multicolumn{7}{|c|}{ Measurements before the removal of the deposit from the partition } \\
\hline 18.09 .17 & 4 & 23.5 & 27 & LO DRY & $\begin{array}{c}33.8 \\
\text { WET }\end{array}$ & HI WET \\
\hline \multicolumn{7}{|c|}{ Measurements after the removal of deposit from the wall using a biocidal agent } \\
\hline 09.10 .17 & 2 & 25 & 26 & LO DRY & $6.4 \mathrm{DRY}$ & LO DRY \\
\hline
\end{tabular}

DRY $(<17)$ - dry substrate, WET $(>20)$-wet substrate, LO- lower than the minimum limit of detection, $\mathrm{HI}-$ higher than the maximum limit of detection

RH (Relative Humidity) e.g. (1) of an air-water mixture is defined as the ratio of the partial pressure of water vapor $\left(\mathrm{H}_{2} \mathrm{O}\right)\left(\mathrm{e}_{\mathrm{w}}\right)$ in the mixture to the equilibrium vapor pressure of water $\left(\mathrm{e}^{*}{ }_{\mathrm{w}}\right)$ at a given temperature.

$$
\phi=\frac{e_{w}}{e^{*}{ }_{w}} \times 100 \%
$$




\section{CONCLUSIONS}

The main cause which initiates the appearance of moulds on building partitions is excessive moisture $(>60 \% \mathrm{RH})$. The longer the water activity in the material is maintained at a level of $\mathrm{a}_{\mathrm{w}}>0.75$ the higher the risk is of infestation with a mould [2]. Plastering, applying finishing coats and performing other work during construction activities require the use of water. Its natural drying in a short time is impossible. The shorter and shorter deadlines and the increasing speed of construction work have resulted in the more and more frequent occurrence of so called technological (building) moisture.

The buildings analysed in the area of Zielona Góra were affected by so called technological moisture which resulted from the excessively fast performance of the finishing work. The measurements of the relative humidity of the air demonstrated that it was maintained at a low level (below 30\% RH). On the other hand, the construction material on the partition which was subjected to analysis was wet and reaches a value that exceeds the measuring scale at the site of occurrence. This is a negative phenomenon which contributed to the occurrence of sites infested with mould on the building partitions. The developing moulds constitute a risk to human health. On top of this, due to the production of caustic metabolites, they can cause changes in the primary properties of the technical material, and as a consequence of this, damage.

In total, 7 species of moulds were isolated from the infested building partitions of an apartment in the developer's block of flats. The largest number of spores belonged to Cladosporium and Alternaria geni, which are common in the environment. The building partitions of the Institute of Environmental Engineering were dominated by Stachybotrys chartarum, which is one of the most dangerous species of moulds in the light of the studies conducted in the residential environment.

The cases described in the article serve as examples that show that attention must be paid to the phenomenon of the technological moisture which is occurring more and more frequently in the construction sector. The problem refers both to newly built and renovated buildings, and its elimination is often treated as an additional service.

\section{REFERENCES}

1. Arora D.K., Mukerji K.G., Marth E.H.: Handbook of Applied Mycology, New York, Marcek Dekker 1991.

2. Andersen B., Frisvad J.C., Sondergaard IB Ib., S. Rasmussen Ib S., Larsen L. S.: Associations between Fungal Species and Water-Damaged Building Materials, Applied and Environmental Microbiology, 2011, p. 4180-4188. 
3. Altamirano-Medina H, Davies M, Ridley I, Mumovic D, Oreszczyn T.: Guidelines to avoid mould growth in buildings. Advances in Building Energy Research, 2009, 3 (1) pp. 221-236.

4. Clontz L.: Microbial limit and bioburden tests: validation approaches and global requirements. 2nd ed. CRC Press Taylor\& Francis Group, Boca Ration London, New York, 2009.

5. Grant C., Hunter C.A., Flannigan B., Bravery A.F.: Water activity requirements of moulds isolated from domestic dwellings. International Biodeterioration, 1989, 25: 259 - 284.

6. Hoekstra E.S, Samson R.A. Summerbell R.C.: Methods for the detection and isolation of fungi in the indoor environments. In: R.A. Samson, E.S. Hoekstra, J.C. Frisvad, (red.) Introduction to food and airborne fungi. Seventh Ed. Utrecht. Centralbureau voor Schimmercultures (CBS) The Netherlands, 2004.

7. Instytut Techniki Budowlanej. Dokument interpretacyjny do Dyrektywy 89/106/EEC dotyczącej wyrobów budowlanych. Wymagania podstawowe, Higiena, zdrowie i środowisko. Warszawa 1995, 3: 58.

8. Piontek M.: Grzyby pleśniowe $i$ ocena zagrożenia mikotoksycznego w budownictwie mieszkaniowym, Oficyna Wydawnicza Uniwersytetu Zielonogórskiego, Zielona Góra, 2004, 174 s.

9. Piontek M. Strains of Aspergillus versicolor Tiraboschi synthesizing sterigmatocistin and the differentiation of mycotoxic risk dependent on their productivity in housing buildings. Mycotoxin Research Vol.23, No. 1 (2007): 34-38.

10. Piontek M., Jasiewicz M., Bednar K.: Wady technologiczne przyczyna występowania grzybów pleśniowych $w$ budownictwie W: Rozkład i korozja mikrobiologiczna materiałów technicznych, V Konferencja Naukowa. Łódź, Politechnika Łódzka, 2009, 115.

11. Piontek M.: Use of planarian Dugesia tigrina Girard bioassay for assessing the toxicity of sterigmatocistin produced by Aspergillus versicolor Tiraboschi. Environment Protection Engineering, 2010, Vol. 36 (1): 65-71.

12. Piontek M., Łuszczyńska K., Lechów H.: Occurrence of the toxin-producing Aspergillus versicolor Tiraboschi in residential buildings. International Journal of Environmental Research and Public Health,2016, Vol. 13 (9): 1-12.

13. Samson R.A, Hoekstra E.S., Frisvad J.C.: Introduction to food and airborne fungi. Seventh Ed. Utrecht. Centralbureau voor Schimmercultures (CBS) The Netherlands, 2004, 389 ss.

14. World Health Organization 2009. WHO guidelines for indoor air quality: dampness and mould.

15. Wójcik R.: Ochrona budynków przed wilgocią i wodą gruntową. W: [Red. Klemm P.]. Budownictwo ogólne, tom 2. Fizyka budowli, Arkady, 2005, 913 - 981. 
16. Zyska B.: Zagrożenia biologiczne w budynku. Warszawa 1999, Arkady, $251 \mathrm{ss}$.

\section{WILGOĆ TECHNOLOGICZNA PRZYCZYNA WYSTĘPOWANIA GRZYBÓW PLEŚNIOWYCH NA PRZEGRODACH BUDOWLANYCH}

\section{Streszczenie}

Szybkie tempo prac budowlanych powoduje, że materiały techniczne zawierają tzw. wilgoć technologiczną, która umożliwia rozwój organizmów biodeteriogennych na przegrodach budowlanych. W artykule przedstawiono badania mikologiczne dwóch obiektów budowlanych w Zielonej Górze, na przegrodach których pojawiły się barwne naloty. W pierwszym budynku (blok mieszkalny w stanie deweloperskim) oznaczono 7 gatunków grzybów pleśniowych, z czego dominującym gatunkiem był Cladosporium herbarum. W drugim obiekcie (budynek użyteczności publicznej) zmiany na scianach pojawiły się tuż po remoncie i były spowodowane przez niebezpieczny dla zdrowia ludzi i zwierząt gatunek grzyba pleśniowego - Strachybotrys chartarum.

Słowa kluczowe: wilgoć technologiczna, biodeterioracja, grzyby pleśniowe, pleśn w budynku

Editor received the manuscript: 02.03 .2018 